\title{
SARUS: A Synthetic Aperture Real-Time Ultrasound System
}

\author{
Jensen, Jørgen Arendt; Holten-Lund, Hans; Nilsson, Ronnie Thorup; Hansen, Martin; Larsen, Ulrik \\ Darling; Domsten, Rune Petter; Tomov, Borislav Gueorguiev; Stuart, Matthias Bo; Nikolov, Svetoslav \\ Ivanov; Pihl, Michael Johannes
}

Total number of authors:

13

Published in:

I E E E Transactions on Ultrasonics, Ferroelectrics and Frequency Control

Link to article, DOI:

10.1109/TUFFC.2013.2770

Publication date:

2013

Document Version

Publisher's PDF, also known as Version of record

Link back to DTU Orbit

Citation (APA):

Jensen, J. A., Holten-Lund, H., Nilsson, R. T., Hansen, M., Larsen, U. D., Domsten, R. P., Tomov, B. G., Stuart, M. B., Nikolov, S. I., Pihl, M. J., Du, Y., Rasmussen, J., \& Rasmussen, M. F. (2013). SARUS: A Synthetic Aperture Real-Time Ultrasound System. I E E E Transactions on Ultrasonics, Ferroelectrics and Frequency Control, 60(9), 1838-1852. https://doi.org/10.1109/TUFFC.2013.2770

\section{General rights}

Copyright and moral rights for the publications made accessible in the public portal are retained by the authors and/or other copyright owners and it is a condition of accessing publications that users recognise and abide by the legal requirements associated with these rights.

- Users may download and print one copy of any publication from the public portal for the purpose of private study or research.

- You may not further distribute the material or use it for any profit-making activity or commercial gain

- You may freely distribute the URL identifying the publication in the public portal 


\section{IEEE TRANSACTIONS ON \\ ULTRASONICS, FERROELECTRICS, AND FREQUENCY CONTROL}

A PUBLICATION OF THE IEEE ULTRASONICS, FERROELECTRICS, AND FREQUENCY CONTROL SOCIETY

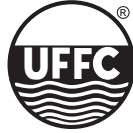

SEPTEMBER $2013 \quad$ VOLUME $60 \quad$ NUMBER $9 \quad$ ITUCER $\quad$ [ISSN 0885-3010]

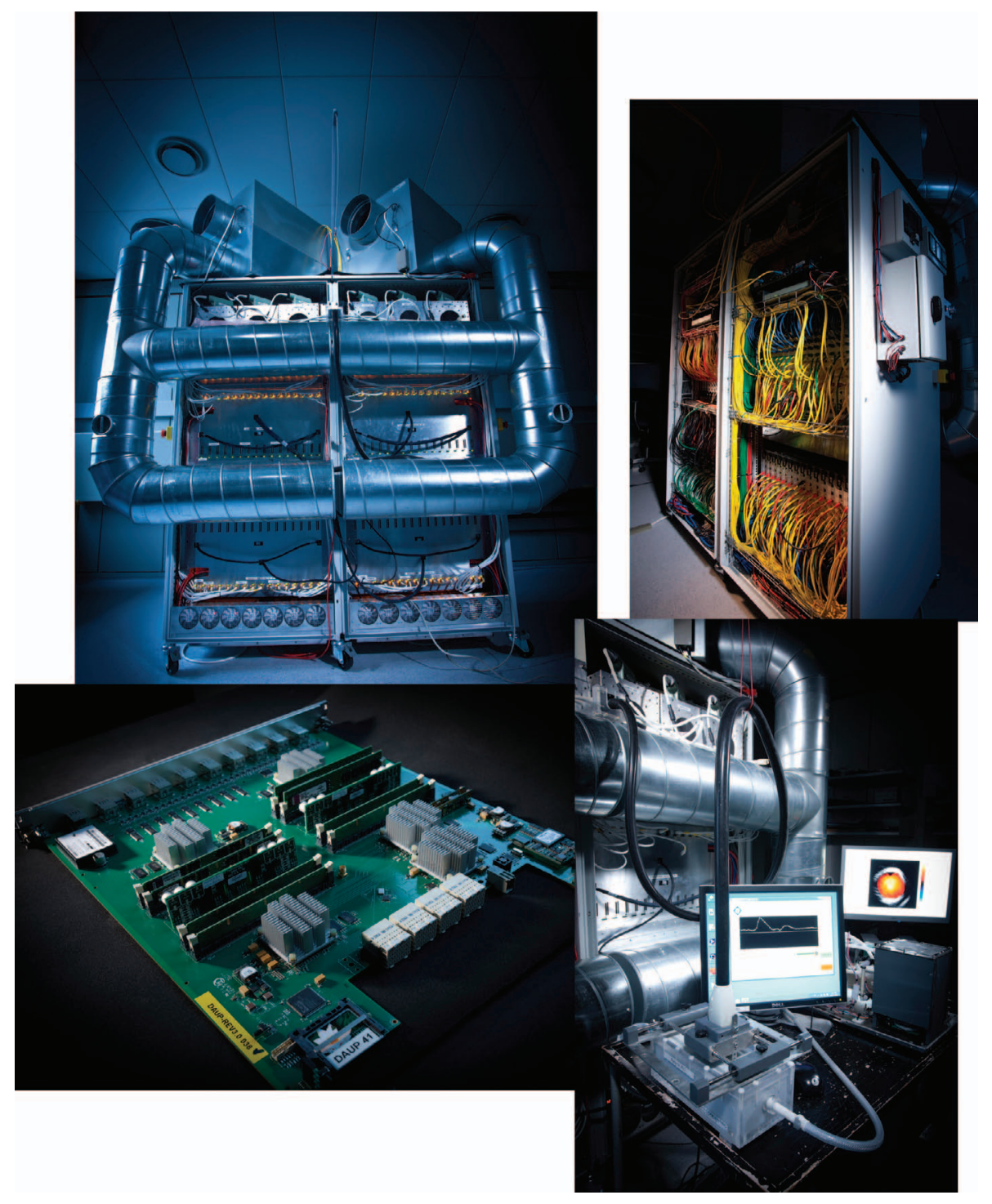




\section{The SARUS (Synthetic Aperture Real-Time Ultrasound System) Research Scanner}

The SARUS research scanner is capable of transmitting and receiving ultrasound signals for 1024 independent transducer elements simultaneously. It can transmit an arbitrary signal on each element, and the signal can change from emission to emission. The RF signal can be received on 1024 elements in parallel at a $70 \mathrm{MHz}$ sampling frequency with a precision of 12 bits. The signals can be stored in real time for several seconds. SARUS can also implement real-time synthetic aperture processing using the 320 FPGAs housed in the system. It is connected through sixty-four 1-Gbit/s links and four 10-Gbit/s links to a Linux computer cluster for fast data storage and off-line processing.

(Top left) The front side of the system, showing the 6 standard transducer connectors at the top of the system and the cooling pipe system. (Top right) The 512 interconnect cables, each with 4 channel connections, between the analog and digital sides of the system. (Bottom left) One of the 64 digital boards in the system. Each board houses 16 transmit and 16 receive channels. Below the 5 heat sinks are the 5 field-programmable gate arrays (FPGAs) that are used for transmission, reception, focusing, summing, and control of the system. (Bottom right) A 2-D $32 \times 32$ channel matrix probe fully connected to the system and used for 3-D vector velocity estimation.

Images were taken by Jens Rosenfeldt and Morten Fischer Rasmussen and provided courtesy of Jørgen Arendt Jensen, the Center for Fast Ultrasound Imaging, Department of Electrical Engineering, Technical University of Denmark, Lyngby, Denmark. For further reading, see the accompanying article on page 1838 of this issue. 